\title{
IMPLEMENTASI MATRIK EFE, MATRIK IFE, MATRIK SWOT DAN QSPM UNTUK MENENTUKAN ALTERNATIF STRATEGI GUNA MENINGKATKAN KEUNGGULAN KOMPETITIF BAGI USAHA PRODUKSI KELOMPOK BURUH PEMBATIK DI KESER NOTOG PATIKRAJA BANYUMAS
}

\author{
Sulasih \\ Dosen FEBI IAIN Purwokerto \\ sulasihs@gmail.com
}

\begin{abstract}
Abstrak
Tujuan Penelitian ini adalah Untuk mengetahui faktor-faktor lingkungan eksternal dan internal dengan menggunakan matrik EFE dan IFE yang mempengaruhi perubahan kompetisi dan mencari alternatifalternatif strategi dengan menggunakan matrik SWOT serta menentukan atau memilih strategi yang paling tepat dengan menggunakan QSPM pada Usaha Produksi Kelompok Buruh Pembatik Di Keser Notog Patikraja Banyumas. Jenis penelitian yang digunakan adalah penelitian deskriptif berdasarkan studi kasus dengan menggunakan pendekatan kualitatif dan kuantitatif. Pengumpulan data terkait dengan penelitian ini dilakukan dengan beberapa tahap yaitu diawali dengan pengumpulan data yang dilakukan melalui wawancara atau melalui Focus Group Discussion (FGD) dengan memberikan kuesioner kepada stakeholder yang terkait. Adapun teknik analisa data yang akan digunakan adalah Matrik Internal Factor Evaluation (IFE), Matrik Eksternal Factor Evaluation (EFE), Matrik Strength,Weakness,Opportunity,Threat (SWOT) dan Matrik Quantitative Strategic Planning Matrik (QSPM). Hasil penelitian ini menunjukan bahwa Strategi dengan membuat corak dan motif batik yang memiliki keunikan merupakan strategi alternatif terbaik untuk diimplementasikan di usaha Produksi Batik di Keser Notog Patikraja Banyumas Jawa Tengah dengan nilai skor TAS sebesar 6,22 pada matrik QSPM. Strategi ini yang paling tepat untuk diterapkan untuk meningkatkan keunggulan kompetitif dalam menghadapi berbagai macam ancaman dan kelemahan dan untuk memperkuat daya saing pada usaha Produksi Batik di Keser Notog Patikraja Banyumas Jawa Tengah.
\end{abstract}

Kata Kunci : Strategi, Keunggulan Kompetitif, Matrik IFE,Matrik EFE, Matrik SWOT, Matrik QSPM.

Abstract
The purpose of this research is to know the external and internal environmental factors by using the
EFE and IFE matrix that lead to the competition changes and seek the alternative strategies by
applying SWOT matrix as well as by specifying or selecting the most appropriate strategy through
QSPM at Batik Labor Group Production on Keser Notog, Patikraja, Banyumas. This research
implemented descriptive research based on the case study that applied qualitative and quantitative
approach. The data collection related to the research was accomplished in several stages. It was started
by interviews or Focus Group Discussion (FGD) by providing questionnaires to the concerned
stakeholders. The data analysis was conducted through Internal Factor Evaluation (IFE) Matrix;
External Factor Evaluation Matrix (EFE) Matrix; Strength, Weakness, Opportunity, Threat (SWOT);
and Quantitative Strategic Planning Matrix (QSPM). The results of this study shows that the strategy
on creating a unique styles and motifs of batik is the best alternative strategy to be implemented in 
Batik Labor Groups Production on Keser Notog, Patikraja, Banyumas, Central Java with the TAS value of 6.22 for QSPM matrix. This strategy is the most appropriate approach to be implemented to enhance the competitive advantage to face the various kinds of threats and weaknesses and to strengthen the competitiveness in business production of Batik in Keser Notog, Patikraja, Banyumas, Central Java.

Keywords: Strategy, Competitive Advantage, IFE Matrix, EFE Matrix, SWOT Matrix, QSPM

\section{A. PENDAHULUAN}

Kabupaten Banyumas memiliki kondisi keamanan daerah yang kondusif, posisi geografis yang strategis, potensi sumber daya alam yang cukup tinggi, serta ketersediaan tenaga kerja. Kondisi tersebut merupakan peluang yang sangat besar untuk peningkatan, pengembangan dan pemberdayaan UMKM/IKM. Berbagai keunggulan dan kekhasan lokal Kabupaten Banyumas perlu terus dikembangkan untuk meraih keunggulan komparatif dan kompetitif dalam perekonomian dunia yang semakin bebas dan sangat kompetitif. Potensi utama atau produk unggulan Kabupaten Banyumas tersebar di 27 Kecamatan di Kabupaten Banyumas diantaranya Patikraja, Sokaraja, Baturaden, Cilongok, Banyumas dan lain sebagainya. Adapun produk unggulan Kabupaten Banyumas terdiri industri makanan, industri minuman dan industri lainnya dengan hasil produksinya diantaranya getuk goreng, tempe, jenang, nopia/mino, gula kelapa, batik dan minyak Atsiri yang mengalami perkembangan, namun beberapa IKM/UKM yang memiliki peluang pasar potensial adalah gula kelapa, minyak atsiri dan kerajinan batik yang selama ini masih perlu dikembangkan.

Di Kabupaten Banyumas terdapat banyak industri kecil penghasil batik, salah satunya di Keser Notog Patikraja Banyumas. Berdasarkan catatan dari Dinas Perindustrian Perdagangan dan Koperasi (Disperindagkop) Kabupaten Banyumas jumlah omset yang dihasilkan oleh pengrajin batik tersebut masih kecil apabila dibandingkan daerah lain hal diantaranya daerah Brebes, Cilacap dan Yogyakarta ini disebabkan kualitas dan kapasitas produksi batik Banyumasan khususnya di Keser Notog Patikraja Banyumas masih sangat terbatas. Di tengah makin tingginya kompetisi di pasar nasional maupun internasional atau di era perdagangan bebas saat ini diperlukan tindakan konkrit agar mampu memberdayakan potensi dan sumber daya daerah sekaligus mendorong laju perekonomian daerah sehingga iklim usaha akan lebih kompetitif baik di dalam maupun luar negeri.

Kelompok Usaha Batik Keser didirikan pada tahun 2013, yang awal mulanya dari Ibu Jaenah membuat mitra usaha yang bekerja sama dengan beberapa ibu wali murid PAUD dan beberapa Ibu Rumah Tangga yang mempunyai bakat membatik secara turun temurun, namun masih banyak kekurangan untuk pengetahuan dan ketrampilan batik tulis yang pada akhirnya beberapa pihak luar desa memberikan pengabdian kepada usaha tersebut berupa pelatihan batik tulis. Beberapa pihak luar yang memberikan pelatihan yaitu Disperindagkop Kabupaten Banyumas, Skb Kalibagor Banyumas, Sehingga kini telah menjual produk batik tulis khas Banyumasan. Kelompok Usaha Batik Keser diharapkan akan dapat menjadi motor penggerak bagi berkembangnya potensi batik Banyumasan.

Dari perkembangannya, saat ini batik Keser telah munculkan berbagai motif, diantaranya pring sedapur, kembang sepatu, smock, manggaran, cipret dan lain sebagainya dengan ciri khas warna hitam dan coklat. Harganya saat ini sangat beragam, untuk yang berkualitas memiliki harga yang tinggi sedangkan harga yang murah juga ada sesuai dengan kualitas dari batik tersebut. Kini ada lagi motif dari batik Keser yang menggambarkan produk unggulan berdasarkan potensi daerah tersebut sebagai 
penghasil singkong yang tidak dijumpai di tempat usaha batik lainnya yaitu kembang kamboja dan singkong kembar.Motif tersebut sengaja diciptakan sebagai bentuk inovasi dari usaha batik Keser.

Analisis dari lingkungan eksternal perlu dilakukan untuk mengantisipasi dampak buruk untuk perusahaan. Selain itu juga untuk mengetahui peluang yang ada yang kemungkinan muncul dari lingkungan eksternal. Pasar yang lebih luas dengan diterapkannya perdagangan bebas dapat memudahkan perusahaan dalam melakukan ekspansi pasar di Negara lain.Lingkungan eksternal memang sulit untuk dikendalikan karena melibatkan pihak-pihak lain yang tidak berhubungan langsung dengan perusahaan. Oleh karena itu analisis lingkungan eksternal (EFE) sangat diperlukan oleh perusahaan khususnya dalam proses perumusan strategi. Analisis internal (IFE) diperlukan perusahaan seperti halnya analisis eksternal. Lingkungan internal untuk mengetahui kelemahan dan kekuatan yang dimiliki oleh perusahaan. Berdasarkan faktor dari lingkungan eksternal dan internal perlu ditentukan alternatif -alternatif strategi dengan menggunakan analisis SWOT yang nantinya akan dipilih salah satu strategi yang paling tepat dengan menggunakan analisis QSPM yang akan digunakan untuk jadikan daya saing untuk menghadapi persaingan bebas.

Dari penjelasan tersebut menggambarkan bahwa Usaha Produksi Kelompok Buruh Pembatik di Keser Notog Patikraja Banyumas sudah berjalan lama tetapi belum mendapatkan pasar dan belum dapat bersaing dengan pembatik-pembatik lainnya sedangkan potensi usaha ini masih bisa dikembangkan sehingga perlu dikaji lebih mendalam faktor ekternal (EFE) dan Internal (IFE) serta alternalit-alternatif strategi (SWOT) serta memilih strategi yang paling tepat yang akan digunakan sebagai daya saing sehingga harapannya usaha pembatik ini tidak musnah diakibatkan ketidakberdayaan dalam menghadapi persaingan yang semakin kompetitif. Berdasarkan hal tersebut diperlukan penelitian lebih lanjut sehingga penulis mengambil judul penelitian implementasi Matrik EFE, Matrik IFE, Matrik SWOT dan QSPM untuk menentukan alternatif strategi guna meningkatkankeunggulan kompetitif bagi usaha Produksi Kelompok Buruh Pembatik Di Keser Notog Patikraja Banyumas.

\section{B. KAJIAN TEORI}

\section{Strategi}

Kata strategi berasal dari bahasa Yunani yang bearti strategos yang artinya komandan militer. Kita sering mendengar kata strategi dalam perang atau pun pertandingan olah raga. Saat ini kata strategi digunakan dalam berbagai bidang antara lain manajemen, perdagangan dan olahraga. Strategi dalam olahraga diperlukan oleh sebuah tim untuk memenangkan sebuah pertandingan. Sama halnya dengan perusahaan yang juga membutuhkan manajemen strategi untuk memenangkan pertandingan di dunia bisnis sesuai dengan tujuan yang telah ditentukan.

Porter (1996) juga ikut mendefinisikan strategi. Strategi menurutnya adalah penciptaan posisi unik dan berharga yang didapatkan dengan melakukan serangkaian aktivitas. Porter juga pernah menuliskan bahwa esensi dari strategi adalah memilih aktivitas yang tidak dilakukan oleh pesaing atau lawan.

Pengertian strategi dari Alfred Chandler yaitu strategi merupakan penetapan sasaran dan tujuan jangka panjang suatu perusahaan atau organisasi dan alokasi sumber daya untuk mencapai tujuan tersebut. Sedangkan menurut Kenichi Ohmae, strategi adalah keunggulan bersaing guna mengubah kekuatan perusahaan atau organisasi sehingga menjadi sebanding atau melebihi kekuatan pesaing dengan cara yang paling efisien. 


\section{Keunggulan Kompetitif}

Keunggulan kompetitif selain yang sudah dikemukan oleh Fred David, keunggulan kompetitif dengan makna lain juga dikemukan didalam bukunya Freddy Rangkuti. Menurut Porter, ada tiga strategi yang dapat dilakukan perusahaan untuk memperoleh keunggulan bersaing, yaitu :cost leadership, differensiasi, fokus.

Perusahaan dapat memperoleh keunggulan bersaing yang lebih tinggi dibandingkan dengan pesaingnya jika dia dapat memberikan harga jual yang lebih murah daripada harga yang diberikan oleh pesaingnya dengan nilai atau kualitas produk yang sama. Harga jual yang lebih rendah dapat dicapai oleh perusahaan tersebut karena dia memanfaatkan skala ekonomis, efisiensi produksi, penggunaan teknologi, kemudahan akses dengan bahan baku dan sebagainya. Misalnya, banyak perusahaan-perusahaan di Negara maju memindahkan industrinya ke Negara lain seperti Indonesia, Malaysia, Vietnam, China dan Thailand agar memeperoleh pasokan bahan baku yang lebih murah dan lebih baik.

Perusahaan juga dapat melakukan strategi differensiasi dengan menciptakan persepsi terhadap nilai tertentu pada konsumennya.Misalnya, persepsi terhadap keunggulan kinerja produk, inovasi produk, pelayanan yang lebih baik, dan brand image yang lebih kompetitif. Strategi fokus juga bisa diterapkan untuk memperoleh keunggulan bersaing sesuai dengan segmentasi dan pasar sasaran yang diharapkan.

\section{Teknik Analisa Data}

Rancangan analisa yang dipergunakan dalam penelitian ini terdiri dari 3 (tiga ) tahap yaitu:

1. Tahap Input, tahap ini terdiri dari IFE dan EFE

a. Matrik Internal Factor Evaluation (IFE)

Analisis lingkungan internal dapat dilakukan dengan menggunakan matrik IFE (internal factor evaluation).Matrik ini serupa dengan matrik EFE (eksternal factor evaluation) yang digunakan dalam analisis lingkungan eksternal.Perbedaannya adalah faktor-faktor yang ditampilkan adalah faktor lingkungan internal yang berupa kelemahan dan kekuatan yang dimiliki perusahaan. Beberapa tahap yang dilakukan dalam membuat matrik IFE adalah

- Melakukan identifikasi faktor sukses kunci internal sebanyak 10-20 faktor.Faktor-faktor tersebut dibagi menjadi dua bagian yaitu kelemahan dan kekuatan yang dimiliki oleh perusahaan.

- Memberikan bobot dengan angka 0 sampai dengan 1.Angka 0 diartikan sebagai faktor yang tidak penting, sedangkan angka 1 diartikan sebagai faktor yang paling penting.

- Setelah memberi bobot maka selanjutnya memberikan rangking dengan ketentuan sebagai beirkut : angka 1 untuk kelemahan utama, angka 2 untuk buka kelemahan utama, angka 3 untuk kekuatan minor, angka 4 untuk kekuatan utama.

- Setelah tersisi bobot dan rangking, maka selanjutnya adalah mengalikan keduanya dan menaruh hasilnya pada kolom skor bobot tertimbang.

- Terakhir jumlahkan skor tertimbang pada stiap faktor untuk menentukan total skor tertimbang perusahaan. 
b. Matrik Eksternal Factor Evaluation (EFE)

Matrik EFE (Eksternal Factor Evaluation) merupakan salah satu matrik yang membantu perusahaan dalam menganalisis faktor lingkungan eksternal. Didalam matrik EFE, faktor lingkungan ekternal dibagi menjadi 2 kunci faktor yaitu peluang dan ancaman. Matrik ini menyediakan tempat untuk pembuat strategi dalam merangkum dan juga mengevaluasi informasi-informasi mengenai lingkungan ekternal perusahaan. Pembuatan matrik ini dapat dijelaskan dalam 5 tahapan berikut :

- Kumpulkan faktor eksternal yang sudah teridentifikasi oleh hasil audit eksternal, kira-kira 10 sampai dengan 20 faktor. Faktor tersebut termasuk peluang dan juga ancaman. Jelaskan dengan spesifik faktor-faktor tersebut dengan menggunakan data kuantitatif seperti persentase, rasio ataupun angka komparatif.

- Berilah bobot pada masing-masing faktor yang telah diidentifikasi tersebut dengan memberikan nilai 0 sampai 1. Angka 0 untuk faktor yang tidak penting sedang angka 1 untuk faktor yang sangat penting. Biasanya peluang akan mendapatkan bobot yang lebih besar daripada ancaman. Namun hal itu bisa saja berbalik jika perusahaan memang sedang benarbenar dalam keadaan sangat terancam.

- Langkah selanjutnya setelah diberikan bobot adalah dengan memberikan rangking. Rangking dinilai dengan angka antara 1 sampai 4. Rangking tersebut menunjukan rangking perusahaan dalam merespon faktor-faktor eksternal. Rangking 4 bearti respon yang superior, 3 bearti respon di atas rata-rata, 2 respon rata-rata, dan terakhir 1 yang bearti respon yang kurang. Jika bobot dinilai dari sisi industri maka rangking dinilai dari sisi perusahaan.

- Selanjutnya dengan mengalikan antara nilai bobot dengan rangking. Hasil perkalian tersebut ada di kolom skor tertimbang atau weigthed score.

- Jumlahkan skor tertimbang dari semua faktor baik itu ancaman maupun peluang.

Hasil dari penjumlahan skor tertimbang ini dapat dijadikan penilaian tentang respon perusahaan terhadap lingkungan eksternal. Nilai skor tertinggi yaitu 4,0 dan yang nilai skor terendah adalah 1,0. Perusahaan yang mendapatkan nilai tinggi bearti sudah memiliki respon yang baik terhadap lingkungan eksternal. Sebaliknya perusahaan yang mendapatkan nilai rendah bearti masih kurang dalam merespons lingkungan eksternal.

1. Tahap Matching, tahap ini dibuat dengan analisis SWOT

Pembuatan matrik SWOT terdiri dari 8 tahapan. Tahap pertama dan kedua adalah mendata faktor peluang dan ancaman dari luar perusahaan. Tahap ketiga dan keempat adalah mendata kekuatan dan kelemahan perusahaan. Tahapan selanjutnya mencocokan keempat faktor itu satu sama lain dengan berpasang-pasangan. Dimana hasil pasangan strateginya berupa S-O, W-O, S-T, W-T.

Adapun penjelasan keempat strategi tersebut sebagai berikut :

- $\quad$ Strategi S-O : strategi ini menggunakan kekuatan yang dimiliki oleh perusahaan guna memanfaatkan peluang yang ada. Misalnya saja ada peluang pengembangan usaha dan perusahaan juga sedang mengalami laba yang cukup tinggi.

- Strategi W-O : dalam strategi ini digunakan untuk mengatasi sebuah kelemahan perusahaan dengan memanfaatkan peluang yang ada. Misalnya ada pesanan produk dalam jumlah besar sedangkan kapasitas produksi perusahaan tidak memadai. Strategi 
yang bisa dilakukan adalah menambah mesin atau melakukan kerja sama dengan perusahaan lain.

- $\quad$ Strategi S-T : strategi ini dilakukan dengan memanfaatkan kekuatan perusahaan dalam menghadapi ancaman dari luar. Misalnya saja terjadi peniruan produk, perusahaan dapat menuntut hak cipta yang dimiliki dari produk tersebut.

- $\quad$ Strategi W-T : strategi ini merupakan strategi untuk bertahan dari ancaman luar sekaligus mengatasi kelemahan yang dimiliki. Situasi ini merupakan situasi yang terburuk bagi perusahaan. Merger dan likuidasi merupakan pilihan strategi yang digunakan oleh perusahaan apabila diposisi ini.

2. Tahap Decision, tahap ini dibuat analisis QSPM

Tahapan dalam pembuatan matrik QSPM sebagai berikut :

- Faktor - faktor yang merupakan daftar kunci eksternal dan internal berada di kolom sebelah kiri.

- $\quad$ Isi bobot pada setiap faktor tersebut yang sesuai dengan matrik EFE dan IFE

- Mencocokan dan mengidentifikasi alternatif-alternatif strategi yang sebaiknya akandiimplementasikan. Strategi ditulis dalam kolom strategi alternative.

- Tentukan skor atraktif (AS), dengan ketentuan nilai : $1=$ tidak atraktif, 2 = agak atraktif, 3 = cukup atraktif, 4 = sangat atraktif . Adapun penentuan pemberian skor berdasarkan keterkaitan faktor-faktor tertentu sesuaidengan strategi yang dipilih.

- Selanjutnya dengan menghitung total atraktif skor (TAS) dengan cara mengalikan skor atraktif dengan bobot faktor kunci.

- $\quad$ Hitung jumlah TAS pada masing-masing kolom strategi. Strategi yang memiliki jumlah TAS terbesar akan menjadi strategi yang dipilih

\section{HASIL DAN PEMBAHASAN}

\section{Matriks Internal Factor Evaluation (IFE)}

Berdasarkan hasil identifikasi terhadap faktor-faktor internal usaha Produksi Batik di Keser Notog Patikraja Banyumas Jawa Tengah didapat beberapa kekuatan dan kelemahan. Selanjutnya faktorfaktor tersebut di berikan bobot dan rating sesuai ketentuan.

Pada analisis didapatkan hasil perhitungan total skor Internal Factor Evaluation (IFE) sebesar 2,95, yang artinya bahwa kondisi usaha Produksi Batik di Keser Notog Patikraja Banyumas Jawa Tengah berada dalam posisi cukup kuat dilihat dari sisi internal. Usaha Produksi Batik Keser ini memeiliki banyak kekuatan dimana nilainya 0,36 diantaranya usaha ini aktif mengikuti kegiatan pameran yang diselenggarakan oleh pemerintah setempat, memberikan kompensasi apabila barang yang dibeli konsumen tidak sesuai dengan kualitas yang diinginkan atau tidak sesuai dengan pesanan, memberikan diskon untuk pembelian dalam jumlah banyak, memperhatikan kualitas sebelum memproduksi dan barang sampai kekonsumen, terus melakukan inovasi sesuai dengan trend yang lagi berkembang, dan melakukan quality control.

\section{Matrik Eksternal Factor Evaluation (EFE)}


Berdasarkan hasil identifikasi terhadap faktor-faktor eksternal usaha Produksi Batik di Keser Notog Patikraja Banyumas Jawa Tengah didapat beberapa peluang dan ancaman. Selanjutnya faktor-faktor tersebut di berikan bobot dan rating sesuai ketentuan

Pada analisis didapatkan hasil perhitungan total skor Eksternal Factor Evaluation (EFE) sebesar 3,41, yang artinya bahwa kondisi usaha Produksi Batik di Keser Notog Patikraja Banyumas Jawa Tengah berada dalam posisi bagus dalam menangkap atau merespon peluang serta mampu menghindari ancaman yang ada dari competitor.

\section{Matrik SWOT}

Matrik SWOT adalah sebuah alat yang bisa digunakan untuk menyusun dan mengembangkan strategi.Faktor-faktor yang bisa digunakan untuk pengembangan strategi meliputi kekuatan (strength), kelemahan (weakness), peluang (opportunity), ancaman (threat). Adapun strategi yang dibentuk melalui matrik SWOT bisa dilihat ditabel 3 dibawah ini :

Tabel 3. Matriks SWOT

Produksi Batik di Keser Notog Patikraja Banyumas Jawa Tengah

\begin{tabular}{|c|c|c|}
\hline EFE & $\begin{array}{l}\text { STRENGTHS (S) } \\
\text { 1. Tingkat penjualan dapat } \\
\text { digunakan untuk } \\
\text { mengembalikan pinjaman dari } \\
\text { luar } \\
\text { 2. Aktif dalam mengikuti } \\
\text { kegiatan pameran yang } \\
\text { diselenggarakan oleh instansi- } \\
\text { instansi } \\
\text { 3. } \begin{array}{l}\text { Dalam menentukan harga jual } \\
\text { memperhatikan segmentasi }\end{array} \\
\text { pasar } \\
\text { Memberikan kompensasi } \\
\text { apabila barang tidak sesuai } \\
\text { dengan pesanan } \\
\text { 5. Memberikan diskon untuk } \\
\text { pembelian partai besar } \\
\text { Melakukan quality control atas } \\
\text { hasil produksi sebelum produk } \\
\text { dipasarkan } \\
\text { Mengikuti perkembangan atau } \\
\text { trend pasar dengan terus } \\
\text { melakukan inovasi } \\
\text { Tingkat Produktifitas dapat } \\
\text { menghasilkan modal kerja } \\
\text { jangka pendek } \\
\text { Mengutamakan kualitas } \\
\text { 10. SDM yang berkualitas dan } \\
\text { terampil }\end{array}$ & 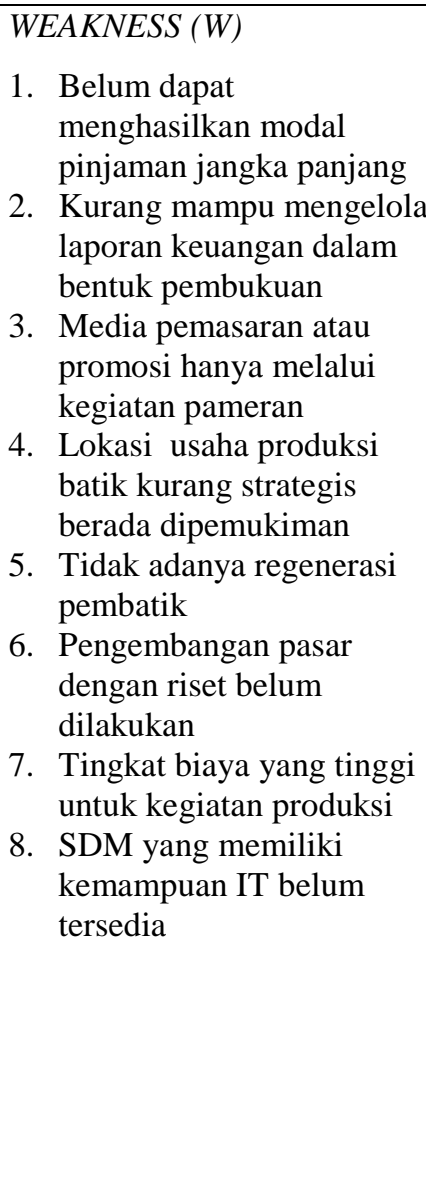 \\
\hline $\begin{array}{l}\text { OPPORTUNITIES }(O) \\
\text { 1. Tingginya tingkat } \\
\text { Pertumbuhan penduduk } \\
\text { membuka peluang akan }\end{array}$ & $\begin{array}{l}\text { STRATEGI SO } \\
\text { 1. Menawarkan produk batik } \\
\text { kebeberapa instansi lain } \\
\text { 2. Meningkatkan inovasi produk }\end{array}$ & $\begin{array}{l}\text { STRATEGI WO } \\
\text { 1. Meningkatkan kerjasama } \\
\text { atau hubungan baik } \\
\text { dengan pemerintah atau }\end{array}$ \\
\hline
\end{tabular}


permintaan batik

2. Beberapa instansi pemerintah memesan batik banyumas untuk seragam dinas

3. Pemerintah setempat memberikan himbauan untuk menggunakan batik banyumas untuk jam kerja tertentu

4. Dinas pemerintah setempat memberikan pelatihan

5. Pemerintah setempat memberikan wadah media untuk melakukan kegiatan pameran

6. Tingkat pertumbuhan jumlah penduduk mempengaruhi tingkat penjualan batik banyumas

7. Jangkauan pasar nasional dan internasional semakin luas

8. Stok bahan baku sangat tercukupi

9. Era perdagangan saat ini berbasis e-commerce

$\operatorname{THREATS}(T)$

1. Peraturan pemerintah terkait import atau perdagangan bebas sehingga banyak produk luar yang lebih murah

2. Tingginya Tingkat inflasi dapat mempengaruhi minat beli batik

3. Bahan baku yang selalu mengalami kenaikan

4. Masyarakat luas banyak belum mengetahui keberadaan batik lokal

5. Banyak beredar Batik printing dimana harganya jauh lebih murah

6. Banyak yang belum mengetahui kualitas perbedaan batik printing dan batik tulis

7. Selain dari banyumas banyak terdapat batik dari luar daerah

8. Tingkat persaingan yang semakin kompetitif

9. Aneka batik yang semakin bervariasi
3. Meningkatkan market share

4. Meningkatkan kualitas produk

5. Memasarkan produk secara online

\section{STRATEGI ST}

1. Meningkatkan kualitas batik lokal (tulis, cap, kombinasi)

2. Memperkuat segmentasi batik lokal

3. Menerapkan strategi harga yang tepat

4. Melakukan pelatihan dan kegiatan workshop terkait perbatikan

5. Membuat corak dan motif batik yang memiliki keunikan instansi-instansi dalam rangka permodalan dan memperluas jaringan bisnis

2. Mengikuti pelatihan terkait pembukuan

3. Melakukan regenerasi dengan melakukan pelatihan kepada anakanak muda dengan corak menarik yang diminati generasi muda

4. Melakukan kegiatan riset pasar untuk mengetahui kepuasan pelanggan

5. Menjalin kerjasama dengan pihak terkait untuk sarana dan prasarana

6. Mengikuti pelatihan terkait e-commerce

7. Memanfaatkan mediamedia online dalam pemasaran

8. Kerjasama dengan pihak terkait dengan produksi sehingga bisa meminimalkan biaya produksi

STRATEGI WT

1. Memanfaatkan media media online dalam pemasaran

2. Meningkatkan loyalitas konsumen terhadap batik banyumas

3. Melakukan strategi khusus sehingga tidak berpengaruh dengan kenaikan harga baku

4. Meningkatkan kualitas batik lokal

5. Melakukan kegiatankegiatan dengan masyarakat dalam rangka mengenalkan batik lokal 


\section{QSPM Matrik}

Setelah melewati tahap analisis strategi melalui berbagai macam matrik yang telah dijelaskan diatas, selanjutnya adalah tahapan pengambilan keputusan. Keputusan yang diambil dapat dilakukan dengan menggunakan matrik QSPM kepanjangan dari Quantitative Strategic Planning Matrix dan bisa dilihat ditabel 4 dibawah ini :

Tabel 4. Matriks QSPM

Produksi Batik di Keser Notog Patikraja Banyumas Jawa Tengah

\begin{tabular}{|c|c|c|c|c|c|c|c|c|c|c|c|}
\hline \multicolumn{2}{|c|}{ Alternatif Strategi } & \multicolumn{2}{|c|}{ S1 } & \multicolumn{2}{|c|}{ S2 } & \multicolumn{2}{|c|}{ S3 } & \multicolumn{2}{|c|}{ S4 } & \multicolumn{2}{|c|}{ S5 } \\
\hline $\begin{array}{l}\text { Faktor-faktor } \\
\text { Utama }\end{array}$ & Bobot & AS & TAS & $\mathrm{AS}$ & TAS & $\mathrm{AS}$ & TAS & AS & TAS & AS & TAS \\
\hline Peluang & & & & & & & & & & & \\
\hline $\begin{array}{l}\text { 1. Tingginya } \\
\text { tingkat } \\
\text { Pertumbuhan } \\
\text { penduduk } \\
\text { membuka } \\
\text { peluang akan } \\
\text { permintaan } \\
\text { batik } \\
\end{array}$ & 0,05 & 4 & 0,20 & 3 & 0,15 & 3 & 0,15 & 3 & 0,15 & 4 & 0,20 \\
\hline \begin{tabular}{|l|} 
2. \\
Beberapa \\
instansi \\
pemerintah \\
memesan batik \\
banyumas \\
untuk seragam \\
dinas \\
\end{tabular} & 0,07 & 3 & 0,21 & 3 & 0,21 & 3 & 0,21 & 3 & 0,21 & 4 & 0,28 \\
\hline $\begin{array}{l}\text { 3. Pemerintah } \\
\text { setempat } \\
\text { memberikan } \\
\text { himbauan untuk } \\
\text { menggunakan } \\
\text { batik banyumas } \\
\text { untuk jam kerja } \\
\text { tertentu }\end{array}$ & 0,06 & 2 & 0,12 & 3 & 0,18 & 3 & 0,18 & 3 & 0,18 & 4 & 0,24 \\
\hline \begin{tabular}{|l|} 
4. \\
Dinas \\
pemerintah \\
setempat \\
memberikan \\
pelatihan \\
\end{tabular} & 0,07 & 3 & 0,21 & 2 & 0,14 & 2 & 0,14 & 4 & 0,28 & 3 & 0,21 \\
\hline \begin{tabular}{|l} 
5. \\
Pemerintah \\
setempat \\
memberikan \\
wadah media \\
untuk \\
melakukan \\
kegiatan \\
pameran \\
\end{tabular} & 0,05 & 2 & 0,10 & 3 & 0,15 & 3 & 0,15 & 4 & 0,20 & 3 & 0,15 \\
\hline $\begin{array}{l}\text { 6. Tingkat } \\
\text { pertumbuhan }\end{array}$ & 0,05 & 4 & 0,20 & 3 & 0,15 & 4 & 0,20 & 3 & 0,15 & 4 & 0,20 \\
\hline
\end{tabular}




\begin{tabular}{|c|c|c|c|c|c|c|c|c|c|c|c|c|}
\hline & $\begin{array}{l}\text { jumlah } \\
\text { penduduk } \\
\text { mempengaruhi } \\
\text { tingkat } \\
\text { penjualan batik } \\
\text { banyumas }\end{array}$ & & & & & & & & & & & \\
\hline 7. & $\begin{array}{l}\text { Jangkauan } \\
\text { pasar nasional } \\
\text { dan } \\
\text { internasional } \\
\text { semakin luas }\end{array}$ & 0,04 & 4 & 0,16 & 2 & 0,08 & 3 & 0,12 & 3 & 0,12 & 4 & 0,16 \\
\hline 8. & $\begin{array}{ll}\text { Stok bahan } \\
\text { baku sangat } \\
\text { tercukupi }\end{array}$ & 0,04 & 2 & 0,08 & 1 & 0,04 & 2 & 0,08 & 2 & 0,08 & 3 & 0,12 \\
\hline 9. & $\begin{array}{l}\text { Era } \\
\text { perdagangan } \\
\text { saat ini berbasis } \\
\text { e-commerce } \\
\end{array}$ & 0,03 & 3 & 0,09 & 3 & 0,09 & 3 & 0,09 & 2 & 0,06 & 4 & 0,12 \\
\hline & Ancaman & & & & & & & & & & & \\
\hline 1. & $\begin{array}{l}\text { Peraturan } \\
\text { pemerintah } \\
\text { terkait import } \\
\text { atau } \\
\text { perdagangan } \\
\text { bebas sehingga } \\
\text { banyak produk } \\
\text { luar yang lebih } \\
\text { murah }\end{array}$ & 0,06 & 2 & 0,12 & 2 & 0,12 & 4 & 0,24 & 2 & 0,12 & 4 & 0,24 \\
\hline 2. & $\begin{array}{l}\text { Tingginya } \\
\text { Tingkat inflasi } \\
\text { dapat } \\
\text { mempengaruhi } \\
\text { minat beli batik }\end{array}$ & 0,06 & 3 & 0,18 & 3 & 0,18 & 4 & 0,24 & 2 & 0,12 & 4 & 0,24 \\
\hline 3. & $\begin{array}{l}\text { Bahan baku } \\
\text { yang selalu } \\
\text { mengalami } \\
\text { kenaikan }\end{array}$ & 0,06 & 2 & 0,12 & 1 & 0,06 & 3 & 0,18 & 1 & 0,06 & 3 & 0,18 \\
\hline 4. & $\begin{array}{l}\text { Masyarakat luas } \\
\text { banyak belum } \\
\text { mengetahui } \\
\text { keberadaan } \\
\text { batik lokal }\end{array}$ & 0,06 & 1 & 0,06 & 2 & 0,12 & 2 & 0,12 & 4 & 0,28 & 3 & 0,18 \\
\hline 5. & $\begin{array}{l}\text { Banyak beredar } \\
\text { Batik printing } \\
\text { dimana } \\
\text { harganya jauh } \\
\text { lebih murah }\end{array}$ & 0,06 & 3 & 0,18 & 2 & 0,12 & 4 & 0,24 & 3 & 0,18 & 4 & 0,24 \\
\hline 6. & $\begin{array}{l}\text { Banyak yang } \\
\text { belum } \\
\text { mengetahui } \\
\text { kualitas } \\
\text { perbedaan batik } \\
\text { printing dan } \\
\text { batik tulis } \\
\end{array}$ & 0,06 & 3 & 0,18 & 2 & 0,12 & 3 & 0,18 & 3 & 0,18 & 4 & 0,24 \\
\hline & $\begin{array}{l}\text { Selain dari } \\
\text { banyumas }\end{array}$ & 0,06 & 3 & 0,18 & 3 & 0,18 & 3 & 0,18 & 3 & 0,18 & 4 & 0,24 \\
\hline
\end{tabular}




\begin{tabular}{|c|c|c|c|c|c|c|c|c|c|c|c|c|}
\hline & $\begin{array}{l}\text { banyak terdapat } \\
\text { batik dari luar } \\
\text { daerah }\end{array}$ & & & & & & & & & & & \\
\hline 8. & $\begin{array}{l}\text { Tingkat } \\
\text { persaingan yang } \\
\text { semakin } \\
\text { kompetitif }\end{array}$ & 0,06 & 3 & 0,18 & 3 & 0,18 & 4 & 0,24 & 3 & 0,18 & 4 & 0,24 \\
\hline 9. & $\begin{array}{l}\text { Aneka batik } \\
\text { yang semakin } \\
\text { bervariasi }\end{array}$ & 0,06 & 3 & 0,18 & 2 & 0,12 & 3 & 0,18 & 2 & 0,12 & 4 & 0,24 \\
\hline & Kekuatan & & & & & & & & & & & \\
\hline 1. & $\begin{array}{l}\text { Tingkat } \\
\text { penjualan dapat } \\
\text { digunakan } \\
\text { untuk } \\
\text { mengembalikan } \\
\text { pinjaman dari } \\
\text { luar }\end{array}$ & 0,07 & 2 & 0,14 & 1 & 0,07 & 2 & 0,14 & 1 & 0,07 & 2 & 0,14 \\
\hline 2. & $\begin{array}{l}\text { Aktif dalam } \\
\text { mengikuti } \\
\text { kegiatan } \\
\text { pameran yang } \\
\text { diselenggarakan } \\
\text { oleh instansi- } \\
\text { instansi } \\
\end{array}$ & 0,09 & 2 & 0,18 & 2 & 0,18 & 2 & 0,18 & 3 & 0,27 & 2 & 0,18 \\
\hline 3. & $\begin{array}{l}\text { Dalam } \\
\text { menentukan } \\
\text { harga jual } \\
\text { memperhatikan } \\
\text { segmentasi } \\
\text { pasar }\end{array}$ & 0,03 & 2 & 0,06 & 4 & 0,12 & 4 & 0,12 & 2 & 0,06 & 3 & 0,09 \\
\hline 4. & $\begin{array}{l}\text { Memberikan } \\
\text { kompensasi } \\
\text { apabila barang } \\
\text { tidak sesuai } \\
\text { dengan pesanan }\end{array}$ & 0,09 & 1 & 0,09 & 2 & 0,18 & 3 & 0,27 & 2 & 0,18 & 2 & 0,18 \\
\hline 5. & $\begin{array}{l}\text { Memberikan } \\
\text { diskon untuk } \\
\text { pembelian } \\
\text { partai besar }\end{array}$ & 0,09 & 1 & 0,09 & 2 & 0,18 & 4 & 0,36 & 2 & 0,18 & 2 & 0,18 \\
\hline 6. & $\begin{array}{l}\text { Melakukan } \\
\text { quality control } \\
\text { atas hasil } \\
\text { produksi } \\
\text { sebelum produk } \\
\text { dipasarkan }\end{array}$ & 0,09 & 2 & 0,18 & 2 & 0,18 & 3 & 0,27 & 3 & 0,27 & 2 & 0,18 \\
\hline 7. & $\begin{array}{l}\text { Mengikuti } \\
\text { perkembangan } \\
\text { atau trend pasar } \\
\text { dengan terus } \\
\text { melakukan } \\
\text { inovasi }\end{array}$ & 0,09 & 4 & 0,36 & 2 & 0,18 & 3 & 0,27 & 3 & 0,27 & 4 & 0,36 \\
\hline 8. & $\begin{array}{l}\text { Tingkat } \\
\text { Produktifitas } \\
\text { dapat }\end{array}$ & 0,07 & 1 & 0,07 & 1 & 0,07 & 3 & 0,21 & 2 & 0,14 & 2 & 0,14 \\
\hline
\end{tabular}




\begin{tabular}{|c|c|c|c|c|c|c|c|c|c|c|c|}
\hline $\begin{array}{l}\text { menghasilkan } \\
\text { modal kerja } \\
\text { jangka pendek }\end{array}$ & & & & & & & & & & & \\
\hline $\begin{array}{l}\text { 9. Mengutamakan } \\
\text { kualitas }\end{array}$ & 0,09 & 4 & 0,36 & 2 & 0,18 & 3 & 0,27 & 4 & 0,36 & 4 & 0,36 \\
\hline $\begin{array}{l}\text { 10. SDM yang } \\
\text { berkualitas dan } \\
\text { terampil }\end{array}$ & 0,05 & 2 & 0,10 & 2 & 0,10 & 3 & 0,15 & 4 & 0,20 & 3 & 0,15 \\
\hline \multicolumn{12}{|l|}{ Kelemahan } \\
\hline $\begin{array}{ll}\text { 1. } & \text { Belum dapat } \\
\text { menghasilkan } \\
\text { modal pinjaman } \\
\text { jangka panjang }\end{array}$ & 0,03 & 1 & 0,03 & 1 & 0,03 & 2 & 0,06 & 2 & 0,06 & 2 & 0,06 \\
\hline \begin{tabular}{|l|} 
2. \\
Kurang mampu \\
mengelola \\
laporan \\
keuangan dalam \\
bentuk \\
pembukuan \\
\end{tabular} & 0,03 & 1 & 0,03 & 1 & 0,03 & 2 & 0,06 & 3 & 0,09 & 2 & 0,06 \\
\hline $\begin{array}{l}\text { 3. } \\
\text { Media } \\
\text { pemasaran atau } \\
\text { promosi hanya } \\
\text { melalui } \\
\text { kegiatan } \\
\text { pameran }\end{array}$ & 0,03 & 1 & 0,03 & 1 & 0,03 & 2 & 0,06 & 3 & 0,09 & 3 & 0,09 \\
\hline 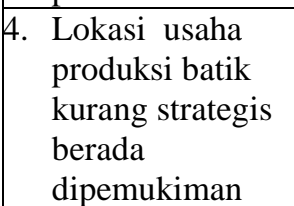 & 0,03 & 1 & 0,03 & 2 & 0,06 & 2 & 0,06 & 2 & 0,06 & 2 & 0,06 \\
\hline $\begin{array}{l}\text { 5. } \text { Tidak adanya } \\
\text { regenerasi } \\
\text { pembatik }\end{array}$ & 0,03 & 1 & 0,03 & 1 & 0,03 & 1 & 0,03 & 4 & 0,12 & 2 & 0,06 \\
\hline $\begin{array}{l}\text { 6. Pengembangan } \\
\text { pasar dengan } \\
\text { riset belum } \\
\text { dilakukan }\end{array}$ & 0,03 & 2 & 0,06 & 1 & 0,03 & 2 & 0,06 & 2 & 0,06 & 3 & 0,09 \\
\hline $\begin{array}{l}\text { 7. Tingkat biaya } \\
\text { yang tinggi } \\
\text { untuk kegiatan } \\
\text { produksi }\end{array}$ & 0,03 & 1 & 0,03 & 1 & 0,03 & 3 & 0,09 & 3 & 0,09 & 2 & 0,06 \\
\hline $\begin{array}{l}\text { 8. } \\
\text { SDM yang } \\
\text { memiliki } \\
\text { kemampuan IT } \\
\text { belum tersedia }\end{array}$ & 0,03 & 1 & 0,03 & 1 & 0,03 & 2 & 0,06 & 3 & 0,09 & 2 & 0,06 \\
\hline Total & & & 4,65 & & 4,10 & & 5,93 & & 5,51 & & 6,22 \\
\hline
\end{tabular}

Berdasarkan data yang diolah dengan QSPM didapatkan bahwa strategi 5 yaitu dengan membuat corak dan motif batik yang memiliki keunikan diharapkan usaha Produksi Batik di Keser Notog Patikraja Banyumas Jawa Tengah ini dapat meningkatkan keunggulan kompetitif diera golbalisasi dan persaingan yang semakin ketat dengan nilai TAS sebesar 6,22. Strategi 3 yaitu usaha Produksi Batik di Keser Notog Patikraja Banyumas Jawa Tengah menerapkan strategi harga yang tepat, dan ini bagian dari upaya untuk semakin bisa meningkatkan keunggulan kompetitif dengan nilai 
TAS 5,93. Sedangkan untuk menunjang tercapainya strategi 9 dan strategi 3 usaha Produksi Batik di Keser Notog Patikraja Banyumas Jawa Tengah direkomendasikan untuk menerapkan strategi 4 yaitu dengan melakukan pelatihan dan kegiatan workshop terkait perbatikan dengan nilai TAS 5,51.

\section{KESIMPULAN}

Penelitian di usaha Produksi Batik di Keser Notog Patikraja Banyumas Jawa Tengah ini menghasilkan beberapa kesimpulan diantaranya :

1. Apabila dilihat dari kondisi internal dan eksternal usaha Produksi Batik di Keser Notog Patikraja Banyumas Jawa Tengah menunjukan kinerja cukup bagus, dengan skor matrik IFE sebesar 2,95. Skor matrik IFE sebesar 2,95 mengidentifikasi bahwa usaha Produksi Batik di Keser Notog Patikraja Banyumas Jawa Tengah memiliki kemampuan dalam memanfaatkan kekuatan dan meminimalkan tingkat kelemahan internal, sedangkan skor matrik EFE adalah 3,41 mengidentifikasi bahwa usaha Produksi Batik di Keser Notog Patikraja Banyumas Jawa Tengah memiliki kemampuan yang bagus dalam memanfaatkan peluang untuk menghindari ancaman dari luar.

2. Berdasarkan analisis rumusan strategi bisnis yang diawali dengan tahap input,tahap pencocokan dan tahap decision didapat sejumlah strategi alternative strategi yang didapatkan dari matrik SWOT diantaranya meningkatkan kualitas batik lokal (tulis,cap,kombinasi), memperkuat segmentasi batik lokal, menerapkan strategi harga yang tepat, melakukan pelatihan dan kegiatan workshop terkait perbatikan dan membuat corak dan motif batik yang memiliki keunikan.

3. Strategi dengan membuat corak dan motif batik yang memiliki keunikan merupakan strategi alternatif terbaik untuk diimplementasikan di usaha Produksi Batik di Keser Notog Patikraja Banyumas Jawa Tengah dengan nilai skor TAS sebesar 6,22 pada matrik QSPM. Strategi ini yang paling tepat untuk diterapkan untuk meningkatkan keunggulan kompetitif dalam menghadapi berbagai macam ancaman dan kelemahan dan untuk memperkuat daya saing pada usaha Produksi Batik di Keser Notog Patikraja Banyumas Jawa Tengah.

\section{E. DAFTAR PUSTAKA}

Agung Praptapa (2009). Strategi Mengendalikan Perusahaan. The Art of Controlling People. PT. Gramedia Pustaka Utama.Jakarta.

David,Fred R (2009). Strategi Management Concept and Cases. Prentice Hall: New Jersey

David, F.R. (2009). Manajemen Strategis. Konsep.Terjemahan Dono Sunardi.Jakarta: Salemba Empat.

Dinas Perindustrian Perdagangan dan Koperasi, Kabupaten Banyumas. Potensi Unggulan Kabupaten Banyumas

Evi Maria dan Kadarusman (2013).penerapanQSPM untuk penentuan alternatif strategi pada STIE Malangkucecwara Malang, Jurnal Manajemen dan Akuntansi Vol 2,No.2

Ferdinand, A (2014). Metode Penelitian Manajemen. Semarang : Penerbit UNDIP

Gomgom Fernando, Sheila Silalahi, manajemen strategic, management student society,FEUI

Glueck,William F dan Jauch,Lawrence,1989. Manajemen Strategi dan Kebijakan Perusahaan ( ${ }^{\text {nd }}$ ed). Erlangga, Jakarta.

Hanny Setyorini, Mas'ud Effendi, Imam Santoso (2016) yang berjudul analisis strategi pemasaran menggunakan matrik SWOT dan QSPM (studi kasus Restoran WS Soekarno Hatta Malang).Jurnal Teknologi dan Manajemen agroindustri Vol 5 No. 1, 46-53 
John A.Pearce. (2009). Manajemen Strategis : Formulasi, Implementasi, Pengendalian. Penerbit Jakarta.

Kraja,Y.dan Osmani,E.(2013). Competitive Advantage and Its Impact in Small and Medium Enterprises (SMEs) (Case of Albania). European Scientific Journal, 9 (16) : 76-85

Pearce,J.A. dan Robinson,R.B. (2013). Manajemen Strategis : Formulasi, Implementasi dan Pengendalian. Terjemahan Nia Permata Sari. Jakarta: Salemba Empat.

Porter, ME. November-Desember (1996). What is Strategy?

Porter, M.E. dan A. Maulana (2008). Strategi Bersaing. Teknik Menganalisis Industry dan Pesaing. Jakarta: Erlangga

Porter.(2008). Keunggulan Kompetitif; Menciptakan dan Mempertahankan Kinerja Unggul.Editor; Saputra dan Suryanto. Tangerang: Karisma Publishing Group.

Rangkuti (2011). Analisis SWOT: Teknik Membedah Kasus Bisnis, Gramedia Pustaka Utama, Jakarta

Rido Pujima Eli Chandra Purba dan E. Kusumadmo. Analisis strategi pemasaran dengan menggunakan metode QSPM di NIMCO Indonesia. Yogyakarta

Senja Nilasari (2014). Manajemen Strategi itu gampang untuk pemula dan orang awam. Penerbit Dunia Cerdas.

Sugiyono (2012).Metode penelitian kuantitatif, kualitatifdan kombinasi (mix method). Bandung: PenerbitAlfabeta.

Sugiyono (2015). Metode Penelitian \& Pengembangan, research and development. Penerbit Alfabeta

Suliyanto.(2011). Analisis Permasalahan Dan Strategi Pengembangan Batik Banyumas Dan Batik Purbalingga. Seminar Internasional Dan Call Papers "Towards Excellent Small Business “ Yogyakarta.

Thomas W.Zimmerer,Norman M.Scarborough (2005). Essentials of Entrepreneurship and Small Business Management. PT. Indeks, Kelompok Gramedia.

Tuatul Mahfud dan Yogiana Mulyani (2017). Aplikasi Metode QSPM; studi kasus strategi peningkatan mutu lulusan program studi tata boga. Jurnal social humaniora dan pendidikan vol. 1 no. 1

Umar,Husein.(2001). Strategic Management in Action. PT. Gramedia Jakarta: Pustaka Utama 